\title{
A new species of ground spiders of the genus Pterotricha Kulczyński, 1903 (Aranei: Gnaphosidae) from Azerbaijan
}

\author{
Новый вид пауков рода Pterotricha Kulczyński, 1903 \\ (Aranei: Gnaphosidae) из Азербайджана
}

\author{
Tamara V. Nuruyeva, Elchin F. Huseynov \\ Т.В. Нуруева, Э.Ф. Гусейнов
}

\begin{abstract}
Institute of Zoology, National Academy of Sciences of Azerbaijan, block 504, passage 1128, Baku Az-1073, Azerbaijan. E-mail: aliyeva_t@mail.ru, apsheron@list.ru

Институт Зоологии Национальной Академии Наук Азербайджана, квартал 504, проезд 1128, Баку Аz-1073, Азербайджан.
\end{abstract}

KEY WORDS: Caucasus, Araneae, Gnaphosinae.

КЛЮЧЕВЫЕ СЛОВА: Кавказ, Araneae, Gnaphosinae.

ABSTRACT. An illustrated description of a new species Pterotricha pseudoparasyriaca sp.n. from Azerbaijan is provided. The new species is closely related to $P$. parasyriaca Levy, 1995 . It has been previously recorded in Azerbaijan as Pterotricha sp.

РЕЗЮМЕ. Приводится иллюстрированное описание нового вида Pterotricha pseudoparasyriaca sp.n. из Азербайджана. Новый вид близок к P. parasyriaca Levy, 1995. Ранее он был отмечен в Азербайджане как Pterotricha sp.

\section{Introduction}

The genus Pterotricha Kulczyński, 1903 was erected by Kulczyński [1903] for Agelena lengitinosa C.L. Koch, 1837. Later, Dalmas [1921] divided it into six genera, with a more strict delimitation of Pterotricha, based on similarity in structure of the copulatory organs and presence of elongated anterior spinnerets. Another important contribution to the systematics of this genus was made by Levy [1995], who redescribed many poorly known species from Northern Africa and the Middle East, and also described several new species from Israel. Altogether, both Dalmas [1921] and Levy [1995] provided illustrations for 22 valid species of Pterotricha [see WSC, 2016]. Recently, Marusik et al. [2013] redescribed P. loeffleri (Roewer, 1955) and suggested that it could be a synonym of $P$. strandi Spassky, 1936.

We have analyzed published descriptions concerning remaining 14 species and our conclusions are as follows. Judging from the illustrations in L. Koch [1875], P. aethiopica (L. Koch, 1875) certainly belongs to Pterotricha. The same is true for P. mauritanica Denis, 1945 [see Denis, 1945]. Somewhat surprisingly, P. tikaderi Gajbe, 1983 described from India
[Gajbe, 1983] very likely also belongs to Pterotricha. Two species from the territory of the former USSR listed under "Pterotricha" in Mikhailov's catalogue [Mikhailov, 2013] were described with insufficient illustrations [Charitonov, 1946; Spassky, 1952] to make any certain conclusion. Two species described by Denis [1966] from Libya most likely belong to another, probably, undescribed genus. The same is true for two Tucker's species from South Africa [Tucker, 1923]. The remaining species were described without illustrations and in some cases even based on juvenile specimens, and their generic placement cannot be confirmed without seeing the types.

In the present paper we describe a new species of Pterotricha from Azerbaijan. It should be mentioned that this is only the third true representative of the genus recorded in the territory of the former USSR [see Mikhailov, 2013]. Earlier, it has been reported from Azerbaijan as Pterotricha sp. [Marusik, Guseinov, 2003].

\section{Material and methods}

The new species was examined, drawn and measured under NYKON SMZ 1270 stereomicroscope. The epigyne of one female was cleared in a solution of potassium hydroxide $(\mathrm{KOH})$ and transferred to ethanol for drawing. Digital images of the palps and epigynes were taken with a digital camera SONY DSC - P8 via ocular of stereomicroscope. All specimens studied in this paper are deposited in the collection of Institute of Zoology, National Academy of Sciences of Azerbaijan, Baku (IZBA), Zoological Museum of the Moscow State University (ZMMU) and Taurida National University (TNU). The following abbreviations are used here for designating of position of spines on legs: $\mathrm{d}$ - dorsal, $\mathrm{p}$ - prolateral, $\mathrm{r}$ - retrolateral, $\mathrm{v}$ - ventral. 


\section{Taxonomy \\ Pterotricha pseudoparasyriaca sp.n.} Figs 1-18.

Pterotricha sp.: Marusik, Guseinov, 2003: 34

MATERIAL: Holotype $\sigma^{7}$ (IZBA), Central-eastern Azerbaijan, Gobustan, Kichik-dash hill, 4007'N, 49²3'E, 29.05.2009 (E.F. Huseynov). Paratypes. 1 (IZBA), same locality, together with holotype; 1 (IZBA), the same area, Beyuk-dash hill, 2.09.1999 (E.F. Huseynov); 2 우 (IZBA), same locality, 5.05.2001 (E.F Huseynov); 1 + , same locality, 18.05.2003 (Yu.M. Marusik); 1 ○', 2 우 (ZMMU), central-eastern Azerbaijan, Absheron Peninsula, Kergez hill, 28.04.2000 (E.F Huseynov); $1 \sigma^{7}$ (TNU), south-eastern Azerbaijan, Lerik Distr., Divagach Vill., $38^{\circ} 41.74^{\prime} \mathrm{N}, 48^{\circ}$ 22.86'E, 25.05.2003 (E.F. Huseynov).

COMPARATIVE MATERIAL. Pterotricha parasyriaca: $1 \sigma^{7}$, Israel, En Zetim NW Zefat (Safed).

ETYMOLOGY. The specific name refers to close similarity with $P$. parasyriaca Levy, 1995 from Israel.

DIAGNOSIS. Male of $P$. pseudoparasyriaca sp.n. is most similar to $P$. parasyriaca. However, in the new species the tip of median apophysis is straight and pointed (Figs 1-2, 11-12), but not curved and bulged as in $P$. parasyriaca (Figs 6-7, 15-16). In addition, the protrusion of apical process of median apophysis in $P$. pseudoparasyriaca sp.n. is pointed and directed horizontally (Figs 1, 11), while in $P$. parasyriaca it is blunt and inclined upward (Figs 6, 16). The tibial apophysis with a single slightly bent tip (Figs 1, 3), bifurcated in $P$. parasyraica (Figs 16, 18). Two species also differ from each other by trajectory of filamentous part of embolus (Figs 1 vs. 6). The anterior margin of the epygine of $P$. pseudoparasyriaca sp.n. is almost straight (Figs 4, 13), while in $P$. parasyriaca it is clearly concave (Fig. 9) and its septum is not connected to the anterior part of the epigyne in contrast to $P$. parasyria$c a$ (Figs 4, 13 vs. 9). There are also differences in the shape of copulatory ducts between two species (Figs 5 , 14-15 vs. 10).

DESCRIPTION. Male. Total length 7.9. Carapace 3.7 long, 3.1 wide. Carapace yellow without pattern. Sternum, labium, chelicerae and maxillae light brown. Abdomen dorsally grey with dark grey spots and brown scutum in anterior part, ventrally light grey. Legs yellow. Scopula on metatarsi and tarsi indistinct. Metatarsi III, IV longer than femora.

Palp as in Figs 1-3, 11-12; with tibial apophysis a little bit slanting upward in horizontal plane with slightly bent tip (Figs 1-3, 11-12). Median apophysis with two extended basal edges and narrow almost straight pointed apical process with distinct pointed protrusion at the middle of it (Figs 1, 11). A long, basally originated embolus ending with very fine loops of stylus (Figs 1, 2).

Leg segment length:

\begin{tabular}{|l|c|c|c|c|c|c|}
\hline & $\mathrm{Fe}$ & $\mathrm{Pa}$ & $\mathrm{Ti}$ & $\mathrm{Mt}$ & $\mathrm{Ta}$ & Total \\
\hline $\mathrm{I}$ & 3.25 & 1.35 & 2.8 & 3.15 & 2.6 & 13.15 \\
\hline II & 2.6 & 0.9 & 2.2 & 2.5 & 1.9 & 10.1 \\
\hline III & 3.6 & 1.65 & 3.15 & 4.18 & 2.3 & 14.78 \\
\hline IV & 4.05 & 1.75 & 3.6 & 5.45 & 3.05 & 17.9 \\
\hline
\end{tabular}

Leg spination in male:

\begin{tabular}{|c|c|c|c|c|}
\hline & $\mathrm{Fe}$ & $\mathrm{Pt}$ & $\mathrm{Ti}$ & Mt \\
\hline I & $\begin{array}{l}\mathrm{d} 1-1-1 \mathrm{p} 0-1-1 \\
\mathrm{r} 0-1-1\end{array}$ & & $\begin{array}{l}\text { p1-1-1 r1-0-0 } \\
\text { v2-2-2 }\end{array}$ & $\begin{array}{l}\mathrm{p} 1-0-1 \mathrm{r} 1-1-0 \\
\mathrm{v} 2-2-2\end{array}$ \\
\hline II & $\mathrm{d} 1-1-0 \mathrm{p} 0-0-1$ & & d1-1-0 p1-0-1 v2-2-0 & v2-2-2 \\
\hline III & $\begin{array}{l}\mathrm{I} 1-1-1 \text { p0-1-1 } \\
\mathrm{r} 0-1-1\end{array}$ & & $\begin{array}{l}\mathrm{d} 2-2-0 \text { p1-0-1 r1-0-1 } \\
\mathrm{v} 2-2-2\end{array}$ & $\begin{array}{l}\mathrm{d} 0-1-0 \\
\mathrm{r} 0-1-0\end{array}$ \\
\hline IV & $\begin{array}{l}\mathrm{d} 1-1-1 \mathrm{p} 0-1-1 \\
\mathrm{r} 0-1-1\end{array}$ & d1 & $\begin{array}{l}\mathrm{d} 2-1-2-1 \text { p1-1-1 r1-1 } \\
\mathrm{v} 2-2-2 \text { 1 }\end{array}$ & $\begin{array}{l}\mathrm{d} 1-1-1 \text { p1-1-0 } \\
\text { r1-1-0 v1-1-1 }\end{array}$ \\
\hline
\end{tabular}

Female. Total length 10.9. Carapace 3.8 long, 3.05 wide. Coloration as in male.

Epigyne as in Figs 4-5, 13-15; with anterior depression of subquadrangular shape, divided by narrow septum widening markedly in the posterior portion (Figs $4,13)$. Vulva with complicated sinuous ducts leading to elongated oval spermathecae (Figs 5, 14-15).

Leg segment length:

\begin{tabular}{|l|l|l|l|l|l|l|}
\hline & $\mathrm{Fe}$ & $\mathrm{Pa}$ & $\mathrm{Ti}$ & $\mathrm{Mt}$ & $\mathrm{Ta}$ & Total \\
\hline I & 3.0 & 1.4 & 2.7 & 2.5 & 2.1 & 11.7 \\
\hline II & 2.95 & 1.2 & 2.3 & 2.58 & 1.95 & 11.03 \\
\hline III & 3.2 & 1.4 & 2.65 & 2.6 & 2.2 & 12.05 \\
\hline IV & 3.6 & 1.6 & 2.85 & 4.25 & 2.3 & 14.6 \\
\hline
\end{tabular}

Leg spination in female:

\begin{tabular}{|c|c|c|c|c|}
\hline & $\mathrm{Fe}$ & $\mathrm{Pt}$ & $\mathrm{Ti}$ & Mt \\
\hline I & d1-1-1 p0-1-1 & & r1-0-1 v2-2-2 & v2-2-2 \\
\hline II & d1-1-1 r0-1-1 & & r1-0-1 v2-2-2 & r0-1-0 v2-2-2 \\
\hline III & $\begin{array}{l}\text { d1-1-1 r0-1-1 } \\
\text { r0-1-1 }\end{array}$ & $\mathrm{p} 1$ & $\begin{array}{l}\mathrm{d} 1-1-0 \text { p1-0-1 } \\
\text { r1-1-1 v2-2-2 }\end{array}$ & $\begin{array}{l}\mathrm{d} 1-1-0 \text { p0-1-0 } \\
\mathrm{r} 1-1-0 \text { v2-2-0 }\end{array}$ \\
\hline IV & $\begin{array}{l}\mathrm{d} 1-1-1 \mathrm{p} 0-0-1 \\
\mathrm{r} 1-0-1\end{array}$ & d1 & $\begin{array}{l}\mathrm{d} 2-1-2-1 \text { p0-1-1 } \\
\mathrm{r} 0-1-1 \text { v2-2-2 }\end{array}$ & $\begin{array}{l}\mathrm{d} 1-2-1-1 \text { p0-1-0 } \\
\mathrm{r} 0-1-0 \text { v2-2-0 }\end{array}$ \\
\hline
\end{tabular}

DISTRIBUTION. The species is known from central-eastern Azerbaijan, Gobustan (the type locality) and the adjacent Apsheron Peninsula [Marusik, Guseinov, 2003, sub Pterotricha sp.], and south-eastern Azerbaijan (Zuvand).

HABITAT. All specimens of $P$. pseudoparasyriaca sp.n. were found during the day time either on the ground or under stones in hot and dry xerophytic landscapes, such as semi-desert and mountain steppe.

ACKNOWLEDGEMENTS. We are very grateful to Yuri M. Marusik (Magadan, Russia) and Kirill G. Mikhailov (Moscow, Russia), and Mykola Kovblyuk (Simferopol, Crimea) as well as anonymous reviewer for their useful comments on the manuscript. We also thank Yuri Marusik and Natalia Snegovaya for providing us with photographs of the copulatory organs of $P$. pseudoparasyriaca and $P$. parasyriaca. We are also obliged to Sergei Zonstein for providing us with specimens of $P$. parasyriaca from Israel. The English of the final draft was kindly checked by Victor Fet (Huntington, USA).

\section{References}

Dalmas R. 1921. Monographie des araignées de la section des Pterotricha (Aran. Gnaphosidae) // Annales de la Société Entomologique de France. T.89. P.233-328. 

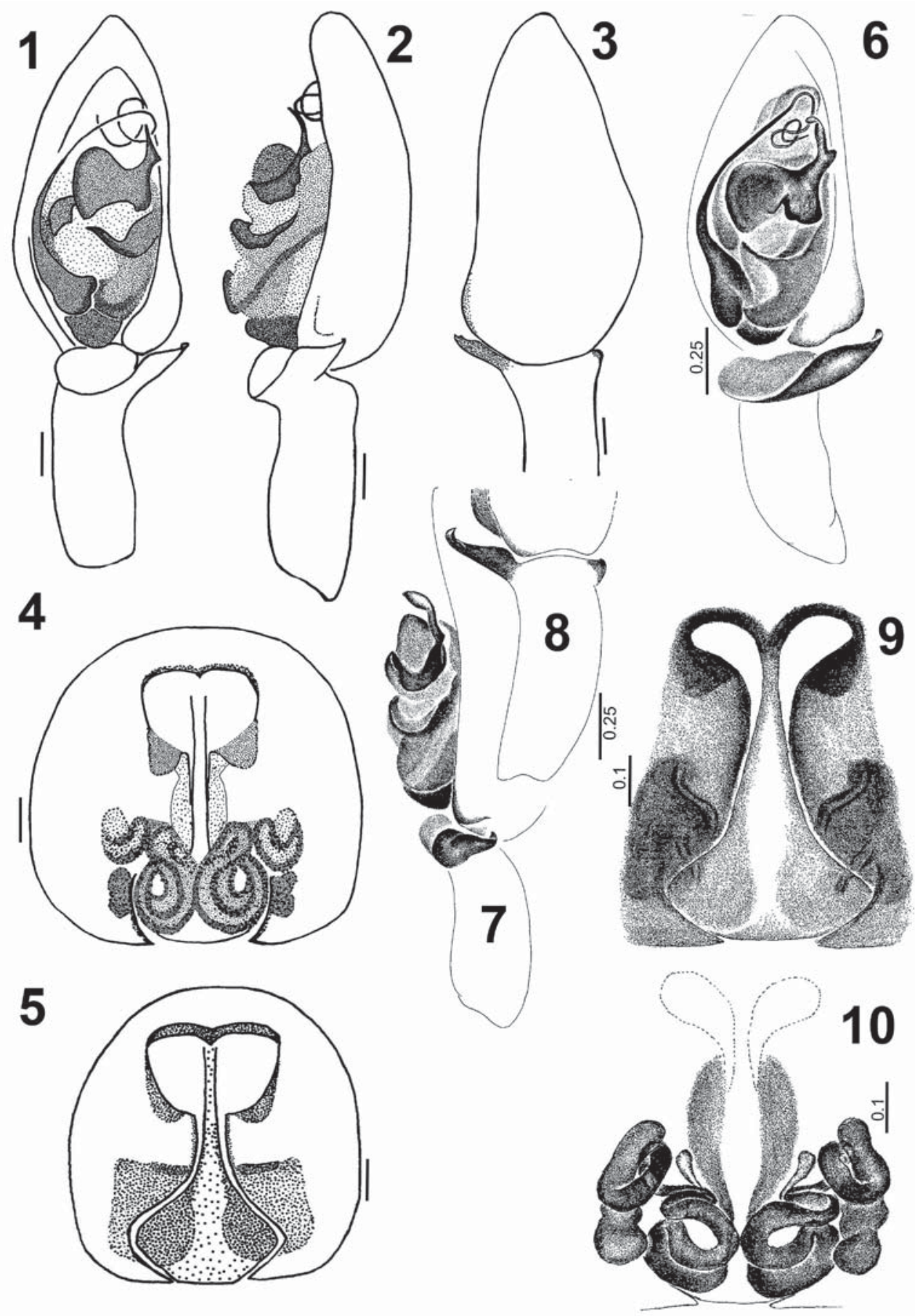

Figs 1-10. Pterotricha pseudoparasyriaca sp.n. (1-5) and P. parasyriaca (6-10): 1-3 - male palp, ventral, retrolateral and dorsal; 4, 9 - epygine; 5, $10-$ endogyne; $6-8-$ male palp, ventral, retrolateral and dorsal; $9-$ epygine; $10-$ endogyne. $6-10-$ after Levy [1995]. Scale $=0.2 \mathrm{~mm}$ if not otherwise indicated.

Рис. 1-10. Pterotricha pseudoparasyriaca sp.n. (1-5) и P. parasyriaca (6-10): 1-3 - пальпа самца, вентрально, ретролатерально и дорсально; 4, 9 - эпигина; 5, 10 - эндогина; 6-8 - пальпа самца, вентрально, ретролатерально и дорсально; 9 - эпигина; 10 - эндогина. 6-10 - по оригинальным рисункам Levy [1995]. Масштаб 0,2 мм, если не указано иначе.

Denis J. 1945. Descriptions d'araignées nord-africaines // Bulletin de la Société d'Histoire Naturelle de Toulouse. T.79. P.41-57.

Denis J. 1966. Les araignées du Fezzân // Bulletin de la Société d'Histoire Naturelle d'Afrique du Nord. T.55. P. 103-144.
Gajbe U.A. 1983. A new Pterotricha spider from India (Araneae: Gnaphosidae) // Bulletin of the Zoological Survey of India. Vol.5. P.95-97.

Kharitonov D.E. 1946. [New forms of spiders of the USSR fauna] // Izvestija Estesvenno-Nauchnogo Instituta pri Molotovskom 

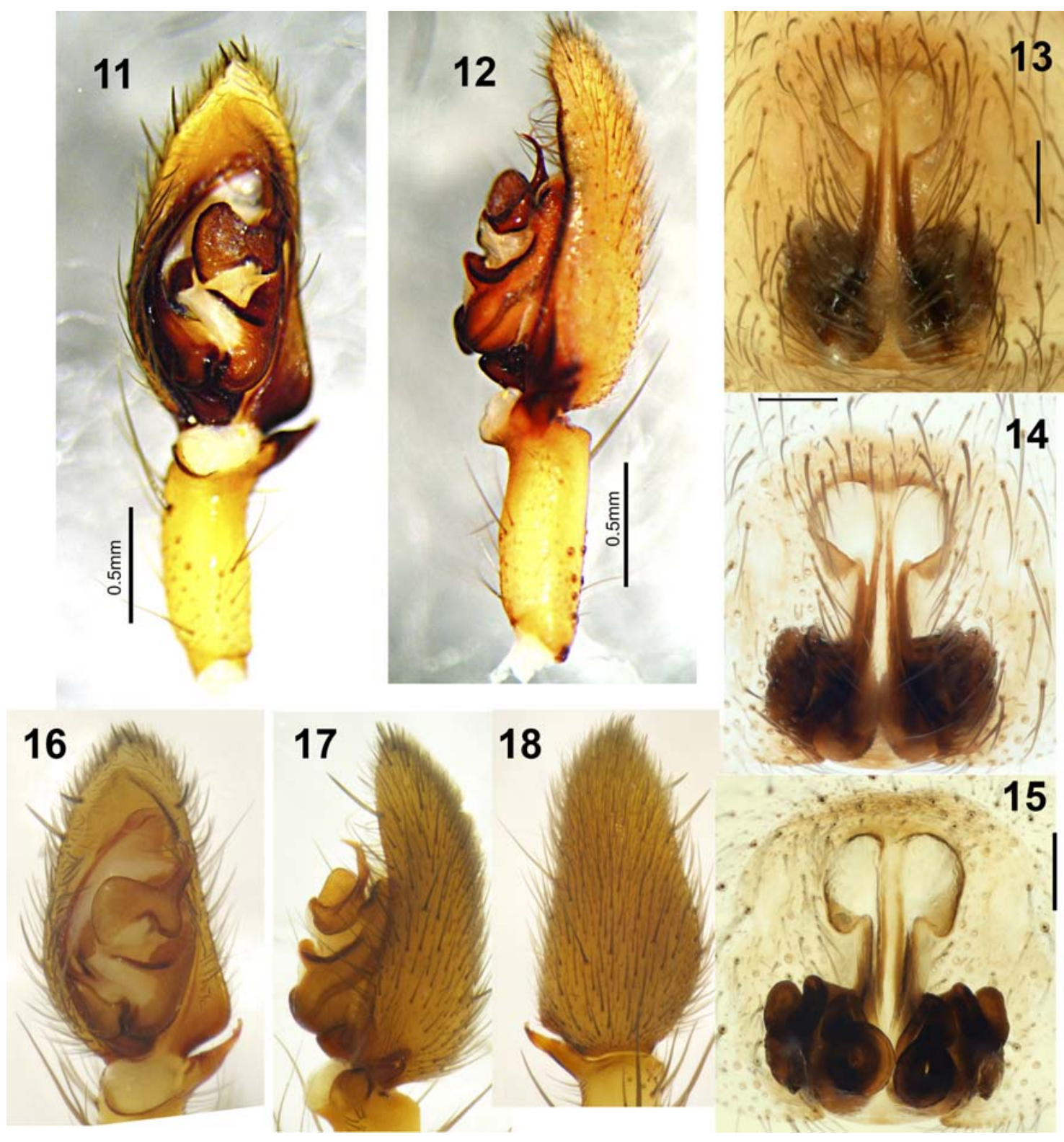

Figs 11-18. Pterotricha pseudoparasyriaca sp.n. (11-15) and P. parasyriaca (16-18): 11-12 - male palp, ventral and retrolateral; 13-14 - epygine before and after maceration; $15-$ endogyne; $16-18-$ male palp, ventral, retrolateral and dorsal. Scale $=0.2 \mathrm{~mm}$ if not otherwise indicated.

Рис. 11-18. Pterotricha pseudoparasyriaca sp.n. (11-15) и P. parasyriaca (16-18): 11-12 - пальпа самца, вентрально и ретролатерально; 13-14 — эпигина до и после мацерации; 15 - эндогина; 16-18 — пальпа самца, вентрально, ретролатерально и дорсально. Масштаб 0,2 мм, если не указано иначе.

Gosudarstvennom Universitete imeni M. Gor'kogo. Vol.12. P.19-32 [in Russian].

Koch L. 1875. Aegyptische und abyssinische Arachniden gesammelt von Herrn C. Jickeli. Nürnberg. S.1-96.

Kulczyński W. 1903. Arachnoidea in Asia Minore et ad Constantinopolim a Dre F. Werner collecta // Sitzungsberichte der Kaiserlichen Akademie der Wissenschaften, Mathematisch-naturwissenschaftliche Klasse, Wien. Bd.112. P.627-680.

Levy G. 1995. Revision of the spider subfamily Gnaphosinae in Israel (Araneae: Gnaphosidae) // Journal of Natural History. Vol.29. P.919-981.

Marusik Y.M., Guseinov E.F. 2003. Spiders (Arachnida: Aranei) of Azerbaijan. 1. New family and genus records // Arthropoda Selecta. Vol.12. No.1. P.29-46.
Marusik Y.M., Omelko M.M., Koponen S. 2013. Redescription of Pterotricha loeffleri (Roewer, 1955) (Aranei: Gnaphosidae: Gnaphosinae) // Arthropoda Selecta. Vol. 22. N.4. P.349-352.

Mikhailov K.G. 2013. The spiders (Arachnida: Aranei) of Russia and adjacent countries: a non-annotated checklist. // Arthropoda Selecta. Supplement No.3. 263 pp.

Spassky S. 1952. [Spiders of the Turanian Zoogeographical Province] // Entomologicheskoe Obozrenie. Vol.32. P.192-205 [in Russian].

Tucker R. W. E. 1923. The Drassidae of South Africa // Annals of the South African Museum. Vol.19. P.251-437.

WSC. 2016. World Spider Catalog, version 17.0. http://www.wsc. nmbe.ch/

Responsible editor Yuri M. Marusik 